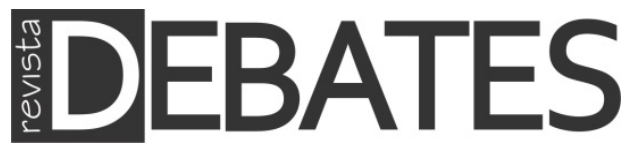

\title{
Inovações democráticas na América Latina
}

\author{
Democratic innovations in Latin America
}

\section{Thamy Pogrebinschi \\ Melisa Ross}

\section{Resumo}

Este artigo objetiva elucidar a rica diversidade de contextos sobrepostos e narrativas singulares que compóem o cenário da inovaçáo democrática na América Latina. Para isso, examinaremos o contexto e as principais tendências das inovaçóes democráticas em cada uma das sub-regióes, a saber, o Cone Sul, a América Central e os Andes. Esta análise é complementada por exemplos emblemáticos de inovaçóes democráticas em 18 países. Por fim, realizamos uma breve avaliação de experimentos participativos da sociedade civil em resposta à pandemia de Covid-19 em 2020 e das implicaçóes da crise sanitária no campo da participação cidadã no continente. $\mathrm{Na}$ conclusão, apontaremos alguns rumos no desenvolvimento de inovações democráticas na América Latina e tentaremos extrair algumas liçóes.

\section{Palavras-chave}

Inovações Democráticas; América Latina; Participação Social; Covid-19.

\section{Abstract}

This article aims to elucidate the rich diversity of overlapping contexts and unique narratives that compose the scenario of democratic innovations in Latin America. To this regard, we will examine the main context and general trends of democratic innovations in each of the sub-regions, namely, the Southern Cone, Central America and the Andes. This analysis is complemented by examples of emblematic democratic innovations and representative cases of social participation in 18 countries. Finally, we conducted a brief assessment of civil society participatory initiatives in response to the Covid-19 pandemic in 2020 and the implications of the health crisis in the field of citizen participation on the continent. In conclusion, we will point out some directions in the development of democratic innovations in Latin America and attempt to draw some lessons.

\section{Keywords}

Democratic Innovations; Latin America; Social Participation; Covid-19. 


\section{Introdução ${ }^{1}$}

Há alguns anos atrás, Fung (2011, p. 857) sugeriu que "muitos de nós talvez voltemos nossos olhos para a América Latina para entender seus avanços em termos de governança democrática". Segundo a opinião do autor, em relação à "vasta gama de reformas democráticas ambiciosas e bem-sucedidas... simplesmente não há analogia de escala e profundidade semelhante na América do Norte, Europa, Ásia ou África” (FUNG, 2011, p. 867). A América Latina de fato tem sido considerada por inúmeros acadêmicos como um laboratório de participação cidadã e inovação democrática (SELEE e PERUZZOTTI, 2009; CAMERON, HERSHBERG e SHARPE, 2012). Embora apenas algumas inovações democráticas que se desenvolveram na região tenham sido investigadas internacionalmente com mais minúcia até o momento como o conhecido orçamento participativo (BAIOCCHI, 2003; WAMPLER, 2007) e os conselhos de saúde (COELHO, 2007) no Brasil, conselhos comunitários na Venezuela (LÓPEZ MAYA, 2008), conselhos consultivos no México (DE LA JARA e VERA, 2012; ZAREMBERG e MUÑOZ, 2012), e consultas prévias na Bolívia (FALLETI e RIOFRANCOS, 2017) - a resiliência, impacto e principalmente o desenho institucional inovativo dessas experiências explicam porque elas chamam tanta atenção e trazem tanta expectativa em relação à participação cidadã na América Latina.

Se a América Latina oferece um solo fértil para que inovaçóes democráticas germinem e deem frutos (como aconteceu com o orçamento participativo, que rapidamente se expandiu para centenas de cidades após sua criação em Porto Alegre em 1989), isso é resultado da interação de diferentes fatores políticos, sociais e culturais. A maioria dos países latino-americanos foram redemocratizados no final do século XX, após períodos de ditadura militar, e muitos promulgaram novas constituiçóes e legislaçôes (ou reformaram significativamente as já existentes), permeando-as com participação cidadã e institucionalizando inovaçóes democráticas como forma de assegurar que a sociedade civil poderia se defender de quaisquer traços restantes de governo autoritário e seria um ator ativo nos novos regimes democráticos (AVRITZER, 2002; PERUZZOTTI e SMULOVITZ, 2006).

Além dessa onda de criação de constituiçóes e reformas legislativas que se seguiram aos processos de democratização, a disseminação de inovaçôes democráticas

\footnotetext{
${ }^{1}$ Este artigo consiste em uma versão expandida e atualizada de nosso capítulo "Democratic Innovations in Latin America" publicado em Stephen Elstub and Oliver Escobar (Eds): Handbook on Democratic Innovations and Governance. London: Edward Elgar Publishing. Para a publicação nesta revista, o artigo foi traduzido por Talissa Barcelos.
} 
também foi favorecida pelas reformas de descentralização que ocorreram em quase todos os países da América Latina (FALLETI, 2005; CAMPBELL, 2003). Conforme o nível local foi ganhando autonomia política e financeira, novas instituições para a participação cidadã foram experimentadas como forma de empoderar comunidades e renovar a administração pública. Ao fortalecer esse terceiro nível administrativo, as reformas de descentralização também expandiram os canais pelos quais organizaçôes da sociedade civil, movimentos de base e cidadãos comuns poderiam participar do processo de políticas públicas. Esses novos canais e instituiçóes participativas se tornaram especialmente relevantes em cidades em que prefeitos de esquerda foram eleitos (GOLDFRANK, 2011).

Os partidos políticos, portanto, também desempenharam um papel importante na abertura das cidades à participaçáo dos cidadãos, uma tendência que se fortaleceu quando partidos de esquerda venceram sucessivamente as eleiçóes nacionais em muitos países latino-americanos. Essa onda de vitórias eleitorais, conhecida como "maré rosa" ou "virada à esquerda", inicialmente começou em nível local, no início dos anos 1990, abrindo caminho para que partidos de esquerda ganhassem eleiçóes presidenciais em cerca de dois terços do continente na primeira década após a virada do século. Embora a ampla diversidade ideológica e os vários graus de institucionalizaçáo dos partidos de esquerda tornem difícil falar de uma única "Esquerda", as diferentes "esquerdas" parecem convergir em pelo menos três pontos: os objetivos programáticos dos partidos de reduzir a desigualdade social e econômica, suas ligaçóes com a sociedade civil e movimentos sociais, e sua vontade de experimentar com a política (LEVITSKY e ROBERTS, 2011).

Esses processos fornecem uma explicação geral de como as inovações democráticas evoluíram no continente, mas existem fatores que são mais comuns a cada sub-região da América Latina, bem como elementos específicos ligados ao contexto histórico e a cultura de cada país. Como resultado, embora diversas instituiçóes e práticas de participação cidadã semelhantes tenham sido adotadas na maioria dos países latino-americanos - incluindo formas de assembleias de cidadãos, como assembleias municipais (cabildos abiertos) e audiências públicas, conselhos deliberativos e de gestão, mesas deliberativas e planos participativos, instâncias de monitoramento e, mais recentemente, também ferramentas de participação digital -, outras inovaçóes democráticas refletem os processos internos enfrentados pelas sub-regióes ou países nos quais se formaram. 
Em 2020, durante a pandemia de COVID-19, os países enfrentaram desafios singulares e também desenvolveram respostas individuais. No entanto, toda a regiāo se encontrou em circunstâncias desfavoráveis em termos de infraestrutura de saúde e da complexidade do problema sanitário. Se até então a participação florescia no continente majoritariamente devido a mudanças institucionais e projetos de governo, a limitada capacidade estatal da maioria dos países acabou por levar a sociedade civil a tomar a frente de um número grande de importantes respostas aos efeitos da pandemia.

Este artigo objetiva elucidar a rica diversidade de contextos sobrepostos e narrativas únicas a cada país que compóe a paisagem em que uma variedade igualmente rica de novas instituições e práticas de participação cidadã foram capazes de criar raízes. Para isso, examinaremos o contexto principal e as tendências gerais das inovaçóes democráticas em cada uma das sub-regiôes da América Latina, a saber, o Cone Sul, a América Central e os Andes ${ }^{2}$. Esta análise é complementada por exemplos de inovaçôes democráticas emblemáticas e casos relevantes que são representativos da paisagem participativa de certos países e que podem ser vistos como de impacto. Por fim, realizamos uma breve avaliação das iniciativas participativas da sociedade civil em resposta à pandemia durante 2020, e as implicaçóes da crise sanitária no cenário da participação cidadã no continente. $\mathrm{Na}$ conclusão, apontaremos alguns rumos no desenvolvimento de inovaçóes democráticas na América Latina e tentaremos extrair algumas liçôes disso.

\section{Inovações democráticas no Cone Sul}

Marcadas por ditaduras militares e pelas condiçôes históricas e institucionais decorrentes, as jovens democracias sul-americanas adotaram novas constituiçóes como elemento crucial de seus processos de transição. Durante a década de 1980, Argentina, Brasil, Chile, Paraguai e Uruguai passaram por reformas constitucionais, remodelando a estrutura do Estado como forma de rompimento com o passado autoritário e a herança das instituiçóes militares (NINO, 1989). A integração de mecanismos deliberativos e participativos foi uma forma de contornar as configuraçóes burocráticas existentes, combatendo a corrupção, garantindo a responsabilização e devolvendo os direitos políticos e sociais a uma sociedade civil lesada, dividida e desigual (O'DONNELL, SCHMITTER e WHITEHEAD, 1986).

\footnotetext{
${ }^{2} \mathrm{O}$ Caribe, assim como Cuba e Haiti, foram excluídos desta análise devido à falta de fontes suficientes e confiáveis.
} 
No Brasil, a Assembleia Constituinte teve uma importância singular, pois o próprio processo de elaboração da nova Constituição foi intensamente participativo. Partidos políticos, organizaçôes da sociedade civil, movimentos sociais e cidadãos comuns estiveram altamente envolvidos na formulação da Constituiçáo de 1988. O texto resultante incorpora o valor da soberania popular, mecanismos de democracia direta e a possibilidade de participação cidadã em todos os três níveis do governo (WAMPLER, 2007; AVRITZER, 2009). O poder devolvido aos municípios permitiu a criação de inovaçóes democráticas, como o orçamento participativo de Porto Alegre em 1989. Vários conselhos de políticas públicas nos quais cidadãos e organizaçôes da sociedade civil têm assento foram institucionalizados e passaram a exercer uma influência muito mais forte após 2003, com a vitória do Partido dos Trabalhadores (PT) na eleição nacional de 2002. A partir daí, vê-se a significativa expansão das Conferências Nacionais de Políticas Públicas, processos escalonados de discussão de recomendaçôes para políticas nacionais que envolveram milhôes de pessoas nos três níveis da federação e que impactaram diversas leis e políticas importantes (POGREBINSCHI e SAMUELS, 2014).

Durante os dois mandatos do presidente Lula, de 2003 a 2010, seguidos pela presidência de Dilma Rousseff, 2011-2016, as inovaçôes participativas no Brasil tiveram origem principalmente no Estado, e em particular, no poder Executivo. Conselhos locais, estaduais e nacionais se fortaleceram em todo o país, visando questóes que abarcam saúde, habitação, e educação, políticas para grupos minoritários e direitos humanos, entre muitos outros. Esses órgãos deliberativos não são apenas espaços de debate entre organizaçóes da sociedade civil, cidadãos comuns e funcionários do governo; eles também estabelecem prioridades, dão recomendações e gerenciam recursos em seus respectivos níveis de competência. Durante esse mesmo período, o Brasil também viu uma expansão nas áreas de governo aberto, direitos digitais e eparticipação em sentido amplo. Foi sob o governo do PT que ocorreu no Brasil o primeiro processo mundial de legislação colaborativa (crowdlaw), a regulamentaçáo do Marco Civil de Internet, que permitiu aos cidadãos e às organizaçôes da sociedade civil elaborar uma lei totalmente nova e inovadora.

Após o impeachment contra a presidente Dilma Rousseff, em 2016, os espaços e canais participativos liderados pelo Estado diminuíram drasticamente no Brasil. Durante a presidência interina de Michael Temer, muitas instâncias de participação foram suspensas ou enfraquecidas (POGREBINSCHI e TANSCHEIT, 2017). Com Jair Bolsonaro, centenas de instituições participativas foram extintas logo no início de 
seu mandato por meio do Decreto No 9.759 de 2018, levando a um processo de desmoronamento da arquitetura institucional da participação social no Brasil.

Desde entáo, a sociedade civil tem reivindicado espaços por meio de mobilizaçôes expressivas e da introdução de mecanismos inovadores. Exemplos são a adoçâo de mecanismos digitais para aumentar a representação política de grupos minoritários, a introdução de mandatos coletivos, e o uso de ferramentas participativas digitais para pautar a atuação dos representantes eleitos e monitorar seu desempenho institucional.

As conjunturas críticas e os processos políticos de resposta às crises definiram o desenvolvimento de inovaçóes democráticas no resto do Cone Sul. Na Argentina, o experimentalismo político e o engajamento cívico se desenvolveram prolificamente durante o colapso político, social e financeiro do país em 2001. Neste período, um grande número de assembleias e conselhos liderados por cidadáos surgiu como uma reaçáo à falta de acesso a bens essenciais e a um Estado ausente e fragmentado ${ }^{3}$. As experiências participativas representaram uma saída para superar as dificuldades econômicas das empobrecidas classes média e baixa, assumindo a gestáo de serviços públicos e de empreendimentos produtivos. Exemplos disso são as Escolas Populares (Bachilleratos Populares), sob gestão conjunta de alunos e professores, e as Assembleias de Bairro (Asambleas Barriales), espaços deliberativos auto organizados que realizam a entrega de bens e serviços básicos no nível da comunidade. Multiplicaram-se também as ocupaçôes de fábricas e sua transformação em cooperativas sob gestão trabalhista e comunitária.

As demandas sociais que surgiram em resposta à crise de 2001 foram abraçadas pelos presidentes Néstor Kirchner durante 2003-2007 e Cristina Fernández de Kirchner (2007-2011 e 2011-2015), que forneceram uma orientação social para políticas participativas para garantir acesso a uma ampla gama de bens e serviços sociais, direitos culturais e para a inclusão política de grupos estruturalmente desfavorecidos (LEVITSKY e MURILLO, 2008). Nesse contexto, a participação tornou-se um meio bastante consolidado de diálogo político e de coadministração em diversas políticas públicas de âmbito local e coordenação nacional. Exemplos são o popular Programa de Melhoria de Bairros (PROMEBA - Programa Mejoramiento de Barrios), um tipo de programa de intervenção local que data dos anos 1990 por meio do qual cidadáos e

\footnotetext{
${ }^{3}$ Ver Sitrin (2006) para um relato da ampla gama de estratégias cidadãs que surgiram em resposta à crise de 2001 e Dinerstein (2003) para uma visão geral da constituição, funcionamento e escopo das assembleias populares surgidas principalmente em Buenos Aires durante a crise.
} 
representantes do Estado trabalham juntos para melhorar os espaços públicos em áreas desfavorecidas. Também foram promovidos pelo governo programas de economia solidária para apoio a agricultores e cooperativas e fortalecimento das cadeias de distribuição locais. Por fim, foram lançados diversos processos de formulação de políticas públicas e legislação nacional a partir de consultas aos cidadãos, organizadas de forma descentralizada e federal, como foi o caso da Reforma do Código Civil (2011) ou da chamada Lei de Meios de Comunicação (2009).

A partir de 2015, sob a presidência do liberal-conservador Mauricio Macri, muitos dos órgãos consultivos em nível nacional deixaram de funcionar na prática, apesar de continuarem a existir formalmente. No entanto, o aumento no acesso às tecnologias digitais se evidencia através da expansão da participação digital por iniciativa da sociedade civil. Tradicionalmente, essas inovaçôes têm se concentrado em questóes de segurança, justiça e prestação de contas (accountability). A plataforma digital DemocracyOS, por exemplo, oferece um espaço virtual para a deliberação e engajamento em tópicos de interesse público. Uma de suas implementaçóes, o projeto DEMOS, permitia que os cidadãos debatessem projetos de lei então em curso na legislatura local de Buenos Aires. Para além disso, várias aplicaçôes permitem aos cidadáos utilizarem os seus smartphones para controlar e reportar o cumprimento da legislação, como é o caso dos regulamentos de preços no varejo por meio do aplicativo Preços Cuidados, ou para possibilitar o acompanhamento de eleiçóes, como nos aplicativos Todos Somos Fiscais, Fiscalizando Argentina e Fiscal Cidadáo. Ferramentas de georreferenciamento digital também são utilizadas para registrar e denunciar crimes, como no Mapa do Crime.

A partir da expansão dos movimentos de mulheres, em particular desde a marcha inaugural do \#NiUnaMenos em 2015, observa-se um aumento nas iniciativas sobre questôes de gênero, violência contra a mulher e desigualdades de gênero. Desde aplicativos que disponibilizam um botáo anti-pânico e outras ferramentas para a segurança da mulher no transporte público, até campanhas digitais para pressionar parlamentares a aprovarem legislação sobre interrupção legal da gravidez, as problemáticas de gênero e desigualdade de gênero têm sido centrais na agenda da inovação na Argentina nos últimos anos.

No Uruguai, por sua vez, o desenvolvimento de inovaçóes democráticas ocorreu após a promulgação da Constituição de 1984, que reforçou o uso de mecanismos de democracia direta, uma tradição duradoura e bem estabelecida no país. Plebiscitos e referendos têm sido amplamente utilizados para a reforma do Estado e 
para decidir sobre questóes públicas importantes (ALTMAN, 2011; LISSIDINI, 2012). Um exemplo notável é o chamado "Plebiscito da Água", originado de uma iniciativa cidadã em 2004 e que, com o apoio de $64,7 \%$ dos cidadáos com direito a voto, consagrou a água como direito humano na Constituição e tornou a sua gestão exclusivamente pública, participativa e sustentável. Os referendos para substituir a Lei das Empresas Públicas, em 1992, e a Lei ANCAP, em 2003, também foram muito importantes politicamente como um meio de descentralizar o poder do Poder Executivo e garantir que o processo de privatização em curso na década de 1990 e início de 2000 fosse mantido sob controle do Estado. Mais recentemente, no entanto, referendos também foram mobilizados pela oposição e por forças conservadoras para restringir direitos. Em 2019 fracassou um pedido de referendo que tentava derrogar a "Lei Trans" (Lei 19694 de 2018) sobre proteção e garantia dos direitos humanos das pessoas transexuais. No mesmo ano, uma iniciativa de reforma constitucional que buscava militarizar a segurança pública foi rejeitada por uma margem de apenas $4 \%$.

Além da tradição de democracia direta no Uruguai, a ascensão ao poder do Frente Amplio, sob a liderança de Tabaré Vázquez (2005-2010 e 2015-2020) e José Mujica (2010-2015), também foi crucial para a implementação de inovaçóes participativas no país (LUNA, 2007). Já com Vázquez como prefeito de Montevidéu entre 1990 e 1994, o Frente Amplio implantou um plano de descentralizaçáo participativa na cidade que, influenciado pelo sucesso de Porto Alegre, institucionalizou progressivamente diversos processos de diálogos e e conselhos de bairro, e, desde 2005, o próprio orçamento participativo. Após a Lei de Descentralização Política e Participação Cidadã de 2010 e a criação do nível municipal, outros municípios também incorporaram o orçamento participativo. No nível nacional, os planos de políticas para o meio ambiente, igualdade de gênero, desenvolvimento rural, direitos humanos e educaçáo têm se baseado em arenas participativas e deliberativas.

Durante seus últimos anos no poder, os governos da Frente Ampla realizaram várias iniciativas de planejamento participativo, onde grupos-alvo específicos são incluídos na identificação de desafios e na elaboração de diretrizes para políticas públicas para enfrentá-los. É o caso da inclusão de afrodescendentes, jovens e idosos no desenvolvimento de programas específicos para atender às suas necessidades. A violência doméstica e a desigualdade de gênero também ganharam centralidade durante as últimas décadas no Uruguai, e foram objeto de deliberação e planejamento participativo. Casos como a Comissão Nacional de Seguimento (CNS) em 1996, o Primeiro Plano Nacional de Igualdade de Oportunidades e Direitos para as Mulheres 
em 2006, e o Conselho Nacional de Gênero em 2007, foram especialmente criados para tratar dessas questóes urgentes.

Finalmente, o país também se destaca por seus avanços em participação digital e governo aberto. Do lado do Estado, tem relevância os projetos de governo aberto, com foco na transparência e no monitoramento pelo cidadão. Do lado da sociedade civil, diversos aplicativos para smartphones que visam monitorar e fortalecer a prestação de contas do Executivo foram desenvolvidos. Plataformas colaborativas como o Por mi Barrio permitem que os cidadáos usem ferramentas de geolocalizaçáo para mapear e gerar dados, canalizando demandas e sugestôes para a administração local de Montevidéu. Mais recentemente, foram criados projetos para monitorar o financiamento dos partidos políticos (QuienPaga.uy), fazer reclamaçôes sobre a destruição do meio ambiente (Reclamaçôes Ambientais UY), ou até mesmo controlar abuso policial (Defensores). O Uruguai é tradicionalmente um país com ótimo desempenho em indicadores de estabilidade institucional e satisfação com a democracia, e o papel das inovaçóes democráticas deveria ser levado em consideração nessas mensuraçóes.

Desenvolvimentos mais recentes ligando instituiçôes participativas e processos de descentralização podem ser observados no Chile e no Paraguai, dois países historicamente mais conservadores que passaram por longos períodos de regime de partido único após suas transiçóes democráticas: pela Coalizão de Partidos pela Democracia (Concertación) e pelo Partido Colorado, respectivamente. A lei do Chile sobre associaçôes e participação cidadá na gestão pública data de 2011 (embora tenha sido redigida e enviada ao parlamento em 2004 sob a presidência de Ricardo Lagos) e, em resposta a uma onda de turbulência social no país, incorpora organizaçóes da sociedade civil no planejamento da gestão pública por meio da criaçáo de conselhos da sociedade civil (COSOC). O processo de descentralização do Paraguai, por sua vez, teve um novo rumo durante a presidência do progressista Fernando Lugo, com a promulgação da Lei Municipal de 2010, que institucionalizou comissóes de bairro que envolvem mais diretamente os cidadáos na gestão local, por exemplo, por meio da elaboração de orçamentos participativos. Outra característica comum a ambos os países é que suas capitais, Santiago, no Chile, e Assunção, no Paraguai, tornaram-se centros importantes de inovação política em seus respectivos países, centralizando muitos dos experimentos participativos.

Embora o Chile tenha passado por várias reformas constitucionais nas últimas quatro décadas, a constituição promulgada em 1980 durante a ditadura de Pinochet 
tem sido uma barreira para o desenvolvimento da participação cidadã e de inovaçóes democráticas no Chile, especialmente devido ao seu processo centralizado e top-down para a formulação e implementação de políticas públicas. Durante a década de 1990, algumas inovações democráticas foram adotadas no nível local. Exemplos são o Chile Barrio - um programa que articula esforços públicos e privados para melhorar as condiçóes de vida e superar a pobreza extrema em assentamentos urbanos irregulares e os Conselhos Regionais - fóruns nos quais os representantes dos cidadãos são eleitos diretamente pela população para debater planos de desenvolvimento regional. As coisas começaram a mudar um pouco durante os mandatos dos presidentes Lagos (20002006) e especialmente Bachelet (2006-2010 e 2014-2018), mas a inovação institucional também se beneficiou do empoderamento dos movimentos sociais após os protestos em massa de 2011, lideradas por estudantes do ensino médio e universitários. Um dos resultados foi a adoção de conselhos deliberativos que auxiliam o Poder Executivo, dando voz a estudantes e populaçóes indígenas, entre outros grupos.

O segundo mandato de Bachelet adotou um papel ativo na promoção da participação cidadá. Inovaçooes democráticas pioneiras foram criadas em nível nacional, como o Conselho Nacional de Participação Cidadã e Fortalecimento da Sociedade Civil, cuja principal missão era assessorar a presidenta em questóes relacionadas à institucionalização da participação cidadâ. Foi sob seu mandato que um caso muito marcante foi realizado: o processo participativo de reforma constitucional, entre 2015 e 2017, que envolveu ativamente os cidadãos na elaboração do esboço para uma nova Constituição. Esse processo compreendeu mecanismos presenciais e uma plataforma on-line (Plataforma Cidadáos Constituintes), e ocorreu nos níveis local e regional, reunindo milhares de cidadãos em reunióes deliberativas. No entanto, e apesar das múltiplas etapas de participação e observação do processo, o esboço concluído no final do mandato de Bachelet náo teve apoio parlamentar para aprovar a reforma constitucional.

É importante destacar que precisamente a reforma constitucional tem sido a reivindicação central dos protestos que tomam as ruas do Chile desde 2019. Os próprios protestos foram organizados por meio de cabildos abertos e assembleias decentralizadas, e reivindicaram a participação direta dos cidadãos na reforma institucional que permitiria combater a desigualdade estrutural que prevalece no país. Pressionado pela extensão das mobilizaçôes, o governo de Sebastián Piñera respondeu criando espaços de diálogo com os movimentos cidadãos. Exemplos são diálogos descentralizados como "O Chile que Queremos", e o Plebiscito de reforma 
constitucional de 2020, que aprovou a convocatória a primeira assembleia constituinte com paridade de gênero no mundo.

No Paraguai, inovaçóes locais realizadas em todo o país, como um sistema nacional de conselhos de saúde, foram adotadas pelo governo desde o início dos anos 1990 com grande sucesso ${ }^{4}$. Esses conselhos têm a capacidade de desenvolver e administrar programas de saúde específicos por meio do trabalho conjunto com organizações da sociedade civil. A partir do ano 2012, e como resposta a escândalos de corrupção e ao impeachment do presidente Lugo, começaram a emergir mecanismos participativos dedicados a monitorar a administração pública e a política, assim como a eficácia de serviços e bens públicos, com o objetivo de fortalecer a transparência e a responsividade (MARSTEINTREDET, LLANOS e NOTES, 2013). Exemplos representativos são o Paraguayoite, um programa criado para que organizaçóes juvenis e estudantis monitorem a distribuição de recursos do Fundo Nacional de Investimento Público e Desenvolvimento (FONACIDE), e o projeto Nañomoiru, para a auditoria social do Tekoporá, um programa de transferência condicional de renda patrocinado pelo Estado. Além disso, diversos projetos baseados na participaçâo digital foram desenvolvidos com a finalidade de acompanhar as eleiçóes e monitorar o cumprimento dos compromissos dos representantes eleitos, como o Voz e Voto, ou para habilitar canais de denúncia durante os dias de eleição, como o Avizor. Adicionalmente, a plataforma \#RegrasClaras reúne diferentes setores e organizaçóes no monitoramento dos processos legislativos.

Assunção também foi palco de outras inovaçôes democráticas interessantes nas áreas de desenvolvimento urbano e gestão local, sob os auspícios do governo municipal. Alguns exemplos são o Asu Viva, um processo de planejamento participativo que atua em conjunto com a sociedade civil para o desenvolvimento inclusivo e sustentável; o Asu Limpa, um projeto de separação e reciclagem de lixo com o apoio das comissóes de bairro; e o Desafio ASU, plataforma web que oferece pesquisa aberta para priorizar projetos de infraestrutura na cidade.

\section{Inovações democráticas na América Central e México}

A América Central tem uma longa e difícil história de conflitos armados e governos autoritários, um cenário desafiador para o engajamento da sociedade civil

\footnotetext{
${ }^{4}$ Rosenbaum, Rodriguez-Acosta e Rojas (2000) apresentam um estudo inicial da descentralização no sistema de saúde paraguaio e seus resultados iniciais, enquanto Gimenez-Caballero, Rodriguez e Peralta (2016) abordam especificamente seus processos de tomada de decisão.
} 
quando o Estado está tanto envolvido em guerras internas quanto lutando contra elas. Desde os anos 1970, movimentos guerrilheiros e forças paramilitares de direita antagonizaram a Nicarágua, El Salvador e Guatemala. É apenas no início da década de 1990 que os acordos de paz e as eleiçóes democráticas acabariam com os conflitos internos nesses países. Esses processos integraram a participação das comunidades afetadas e permitiram que a sociedade civil desempenhasse um papel importante na definição de prioridades e dos contornos dos novos cenários políticos em cada país (DOMINGUEZ e LINDENBERG, 1997).

$\mathrm{Na}$ Nicarágua, diálogos de paz e assembleias de cidadãos organizadas por meio de instâncias municipais setoriais e territoriais construíram a etapa preliminar para a elaboraçâo da Constituição de 1987. O processo contou fortemente com o engajamento da sociedade civil e garantiu a inclusão dos direitos de participação e o conceito de democracia participativa no texto constitucional. A partir de então, foram promulgadas mais de 30 leis fortalecendo a autonomia dos municípios (incluindo a Lei de Descentralização Administrativa, de 1998) e promovendo o envolvimento da sociedade civil na criação, formulação e avaliação de políticas públicas.

A Lei de Participação Cidadã de 2003, conhecida como Lei 475, concedeu institucionalidade a vários novos mecanismos de participação, tais como iniciativas e consultas aos cidadãos em todos os níveis, e aprimorou outros já existentes, incluindo assembleias municipais, comitês de desenvolvimento e petiçôes de cidadãos. Entre eles, destacam-se os chamados Conselhos do Poder Cidadão, órgãos que permitem a participação direta na gestão pública e nos processos de tomada de decisão do governo central. Seus 150 membros devem monitorar e controlar a administração pública, além de canalizar as necessidades das comunidades nos níveis regional, distrital e municipal, tanto em áreas urbanas quanto rurais ${ }^{5}$. Por outro lado, alguns órgãos de participaçáo criados e administrados no âmbito federal (como os Comitês de Defesa) têm sido criticados por constituírem espaços de proselitismo e por serem ocupados por ativistas do partido no poder, o Frente Sandinista de Liberación Nacional (FSLN).

No entanto, os protestos em massa de 2018 contra a corrupçáo e o clientelismo no regime sandinista foram recebidos com repressáo violenta e proibiçáo de manifestações políticas. Apesar de algumas tentativas de gerar uma solução pacífica para o conflito, como por meio dos Diálogos Nacionais de 2018, a virada autoritária do governo de Daniel Ortega tem motivado a sociedade civil organizada a continuar sua

\footnotetext{
${ }^{5}$ Para um estudo abrangente dos Conselhos de Poder do Cidadão, sua estrutura interna e seu impacto no nível da comunidade, consultar Bay-Meyer (2013).
} 
construção democrática por outras vias. Diversos observatórios foram lançados pela sociedade civil e organizaçóes internacionais para monitorar a violência política e as violações dos direitos humanos. Ao mesmo tempo, coalizóes de grupos e movimentos sociais lançaram a Agenda País, um catálogo de reformas necessárias para recuperar a institucionalidade democrática no país, desenvolvido por meio de um processo de diálogo envolvendo diversos atores em todos os níveis do governo.

$\mathrm{Na}$ Guatemala, o processo de descentralização que se seguiu à democratizaçáo do país a partir de 1985 permitiu o desenvolvimento de várias inovaçóes democráticas em diferentes níveis da administração pública. Um exemplo importante é o SICODE (Sistema de Conselhos de Desenvolvimento), um esquema de órgãos participativos nos níveis comunitário, municipal, departamental e regional, que permitem que os cidadãos projetem, implementem e avaliem políticas de desenvolvimento e inclusão. Eles também têm uma função de monitoramento, fiscalizando as próprias políticas e os agentes públicos, além de informar a comunidade sobre a gestão dos recursos. Até 2010, mais de 12.819 desses conselhos tinham sido criados em todo o país (MCNULTY, 2015).

Em 1996, os Acordos de Paz puseram fim à guerra civil e ao genocídio Ixil, e foram acompanhados por iniciativas participativas que posteriormente se transformaram em políticas públicas respaldadas por agências de cooperaçáo internacional. É o caso das Mesas Intersectoriales, espaços promovidos pelas Naçóes Unidas para avaliar o andamento dos compromissos assumidos nos acordos de paz e reinserir a sociedade civil na concepção das políticas sociais e das estratégias de defesa. Outro exemplo é a Comissão Internacional contra a Impunidade na Guatemala, um órgão internacional independente que investiga organizações de segurança clandestinas e que reforçou o monitoramento do sistema de justiça criminal por parte dos cidadáos. Várias inovaçóes relevantes na Guatemala concentraram-se adicionalmente em promover o diálogo e o consenso com os povos indígenas. Exemplos são a Agenda de Desenvolvimento dos Povos Indígenas ou a Mesa Indígena de Mudanças Climáticas para a proteção do meio ambiente; as Comunidades Florestais, que possibilitam o manejo comunitário de áreas de conservaçáo para o desenvolvimento sustentável; e, na área de segurança, os conselhos de segurança locais e programas de segurança de bairro, que envolvem os cidadãos na implementação de estratégias comunitárias para a redução do crime.

A sociedade civil guatemalteca também se mobilizou amplamente no combate à corrupção, levando à renúncia do presidente Otto Perez Molina e exigindo também 
a renúncia de Jimmy Morales no mandato sucessivo por acusaçóes de corrupção e assédio. Neste contexto, ferramentas digitais foram implementadas para melhorar a transparência e permitir o controle cidadão sobre os processos políticos. Assim, plataformas como Eleições Visíveis, campanhas como \#DateCuenta e aplicativos como Eleiçôes MP foram algumas das respostas desenvolvidas por grupos civis em vista as eleiçôes de 2019.

Em El Salvador, os Acordos de Paz de 1992 incluíram a transformação do exgrupo guerrilheiro Frente Farabundo Martí de Liberación Nacional (FMLN) em um partido político, que começou a ganhar terreno no nível local em um contexto difícil de militarização e regime autoritário. Com Mauricio Funes o FMLN chega à presidência em 2009, e durante sua gestão as organizaçóes comunitárias e assembleias de cidadãos começam a se expandir, formando uma rede nacional de comitês zonais, setoriais, municipais e rurais. Também foram criadas assembleias departamentais de cidadãos, que reúnem representantes locais e vizinhos para abordar problemas atuais e debater as diretrizes estratégicas para a administração pública.

Além disso, desde pelo menos 1997, os organismos internacionais têm apoiado a adoção de mecanismos de planejamento participativo para o investimento público em políticas de desenvolvimento, como é o caso do Plano Nacional de Desenvolvimento, Proteção e Inclusão Social, apoiado pela Comissão Econômica das Naçôes Unidas para a América Latina e Caribe (CEPAL) e a agência de cooperação espanhola AECID. Outro caso importante de planejamento participativo são os Planos Quinquenais, políticas públicas de desenvolvimento ao longo prazo formuladas em várias etapas de deliberaçáo e consulta com a sociedade civil, especialistas e o setor privado. A edição mais recente desse processo de diálogo, que teve como objetivo a elaboração do plano 2014-2019, envolveu mais de 13 mil participantes.

Porém, o aumento exponencial da violência nos últimos anos, assim como os fluxos migratórios causados pelas guerras de gangues e a virada autoritária do governo de Nayib Bukele têm apresentado um cenário difícil para a organização dos setores civis. Algumas iniciativas digitais foram desenvolvidas com o objetivo de melhorar as condiçôes urbanas, como os aplicativos Sívar e TeclApp, enquanto outras têm se dedicado a perseguir a corrupçáo, como o aplicativo Controle Cidadão ou o Observatório do Cidadáo ao Tribunal de Contas da República.

Em Honduras, tanto os períodos de autoritarismo militar como os conflitos com as guerrilhas ocorreram em uma escala muito menor do que nos países vizinhos, permitindo uma transiçáo mais pacífica no início da década de 1980 . No entanto, o regime democrático foi novamente interrompido quando um golpe de estado pôs fim 
ao mandato do presidente Manuel Zelaya em 2009. Desde então, demandas da sociedade civil para um maior envolvimento nos processos políticos e na gestão pública levaram os governos de Lobo Sosa e Juan Orlando Hernández a desenvolver novos projetos institucionais para dar espaço à participação dos cidadáos. Exemplos disso são os Conselhos Nacionais de educação, política da juventude, competitividade e inovação, alimentação e nutrição, e emprego.

Uma lei de descentralizaçáo foi promulgada em 2016, acrescentando-se à Lei de Participação Cidadã de 2006. Neste contexto, conselhos e comitês que reúnem representantes da sociedade civil e funcionários do governo foram incorporados em diversas áreas, como no Fórum Nacional de Reforma e Desenvolvimento Agrário e no Fórum Nacional de Participação Cidadã. Além desses, os Conselhos de Gestão da Água responsabilizaram os cidadãos pela operação, manutenção e administração dos sistemas de abastecimento de água potável e saneamento nas áreas rurais e urbanas em desenvolvimento. Em 2016, havia cerca de 5 mil desses órgãos de água ativos em cidades, municípios e vilarejos hondurenhos. Em anos mais recentes, questôes sobre a gestão dos recursos naturais têm pautado a agenda pública e motivado novos processos participativos. Exemplos disso são as Mesas Agroclimáticas Participativas a nível regional, e consultas sobre concessões de mineraçáo, a nível local.

Em nítido contraste com o resto da América Central, a Costa Rica é um caso notável de democracia estável combinada com governança participativa desde sua origem. O instrumento de revogação do mandato data de 1844, e uma incipiente institucionalização da participação encontra-se na Constituição de 1949. Além disso, a reforma constitucional de 2002-2003 incluiu a definição do governo da Costa Rica como "popular, representativo, participativo, alternativo e responsável".

Graças à sua mais recente lei de descentralização de 2010, a Costa Rica também conta com um forte sistema local desenvolvido com base em meios de democracia direta, como plebiscitos, audiências públicas, revogação popular e consultas. Um amplo leque de políticas está nas mãos dos conselhos e comitês comunitários, em particular para a deliberação de estratégias e o estabelecimento de objetivos e agendas, como é o caso dos Conselhos Distritais e dos Órgáos Especializados de Planejamento Local e Regional. A gestão do solo e da água, bem como a conservação dos recursos naturais, são temas recorrentes no diálogo entre o Estado e a sociedade civil. A elaboração coletiva dos Planos Nacionais de Desenvolvimento, juntamente com sua execução e monitoramento colaborativos, são ulteriores mecanismos que visam colocar o governo e a sociedade civil organizada em colaboração. 
O país se destaca adicionalmente pelos esforços tanto do governo como da sociedade civil para avançar no campo do governo digital e de dados abertos. A Costa Rica está, de fato, entre os pioneiros da região em matéria de abertura de dados, aprovando e monitorando, até o momento, 4 planos de governo aberto de forma participativa. No âmbito nacional foram criados diversos estágios de diálogo para avançar na área de digitalização e transparência de dados, incluindo a plataforma "Eu sou Governo Aberto", a Comissão Nacional de Dados Abertos, e a Mesa de Trabalho para uma Justiça Aberta. Além disso, a sociedade civil promove iniciativas de monitoramento desses avanços, como através do Índice de Dados Abertos.

A institucionalização das inovaçôes participativas também tem registrado avanços em outros países da América Central. O Panamá, por exemplo, possui uma tradição significativa de democracia direta por meio de consultas públicas, apesar de sua não muito longínqua transformação em uma democracia independente ${ }^{6}$. $\mathrm{O}$ país tem conduzido diálogos e plebiscitos nacionais para a Reforma Constitucional (em 1991 e 1998), bem como para a gestão de grandes questôes relativas ao Canal (em 2006). No nível local, consultas públicas e debates são realizadas regularmente com os cidadãos, por exemplo, sobre reformas no uso da terra. Somente no distrito da Cidade do Panamá ocorreram, por exemplo, mais de 50 consultas e mais de 100 debates desde 2016.

Na República Dominicana, por sua vez, um amplo processo de reforma administrativa e modernização começou em 1996, incluindo a formalização de estruturas participativas em diversos níveis a partir da aprovaçấo da Lei no ${ }^{\circ} 176$ de 2007. Esta lei torna mandatória a institucionalização em todos os três níveis do governo de Orçamentos Participativos, Comitês de Controle e Acompanhamento, Conselhos Econômicos e Sociais, Comitês de Auditoria Social, Conselhos de Cidade Aberta, e Planos de Desenvolvimento Participativo. Duas reformas constitucionais, em 2010 e 2015 , introduziram também as figuras da iniciativa legislativa popular e plebiscitos e referendos municipais e nacionais.

O México se destaca na região não apenas geográfica, econômica e demograficamente, mas também por sua trajetória institucional. O país foi governado por um único partido de 1929 a 2000. Após significativas reformas institucionais para a descentralizaçáo, já na década de 1980, começaram a surgir espaços de deliberação

\footnotetext{
${ }^{6}$ O Panamá se tornou independente da Colômbia em 1903 e adquiriu, quase imediatamente, o status de protetorado dos Estados Unidos (1903-1931). Após um regime militar de 1968 e a invasão militar dos EUA em 1989, o país só conseguiu realizar sua primeira eleição democrática em 1994.
} 
que permitiram o planejamento conjunto de assuntos públicos relevantes nos níveis local e regional, por exemplo, por meio dos Comitês de Planejamento para o Desenvolvimento Municipal. Mas foi somente com a mudança de governo em $2000 \mathrm{e}$ a vitória do Partido Acción Nacional (PAN) que as inovaçóes democráticas promovidas pelo Estado de fato começaram a se expandir, frequentemente na forma de conselhos locais e nacionais, visando à consulta para a melhoria da governança e eficiência da gestão pública. É o caso dos Conselhos Nacionais de Prevenção à Discriminação, Monitoramento dos Direitos Humanos, Desenvolvimento dos Povos Indígenas, Água e Desenvolvimento Rural Sustentável.

As iniciativas da sociedade civil, por sua vez, têm se concentrado em questóes que afetam mais gravemente a sociedade mexicana, a saber: corrupção, impunidade, crime organizado, e violaçóes de direitos humanos. O monitoramento de autoridades públicas nessas áreas, assim como de eleiçôes e desempenho institucional, depende consideravelmente de mecanismos digitais e financiamento internacional. O Sistema Nacional de Combate à Corrupçáo, por exemplo, faz parte de um esforço do Estado para reunir organizaçóes sociais e especialistas com representantes do governo para fortalecer a transparência e combater a corrupção. Por outro lado, as inovaçóes digitais ganharam recentemente enorme relevância como um recurso de apoio para famílias e associaçôes de vítimas na luta contra a violência organizada e o tráfico de drogas. Aplicativos de smartphone como o Pawah! e plataformas como Nos Faltam Mais permitem que ativistas e a sociedade civil registrem violaçóes de direitos humanos, enquanto projetos de supervisão digital como NarcoData e Memoria y Verdad disseminam informaçóes e promovem a responsabilização.

Com a eleição histórica de Andrés Manuel López Obrador (AMLO) em 2018, os mecanismos de democracia direta ganharam impulso como parte do projeto do governo que seu partido, Morena, chama de "Quarta Transformação". Várias consultas públicas, referendos e fóruns nacionais foram implementados nos últimos anos, mas as iniciativas participativas de AMLO têm sido também criticadas por sua organização defeituosa e por serem conduzidas por fora das instituições, aumentando a incerteza quanto à validade e legitimidade dos resultados. Apesar das críticas, a maioria das iniciativas teve resultados vinculantes, como a consultas sobre a construçáo do Aeroporto Internacional em Texcoco ou para colocar em operação a Usina Termelétrica de Morelos.

Finalmente, uma preocupação comum à maioria dos países centro-americanos é o combate à corrupção e o desenvolvimento de ferramentas participativas de 
transparência e monitoramento da gestão pública. Adicionalmente, dada a instabilidade política que caracteriza a região, o estabelecimento de instituiçóes representativas e mecanismos participativos resultou em grande medida de influências externas. Nas décadas de 1980 e 1990, a pressão internacional foi essencial para impulsar a criação de regras eleitorais e fortalecer a estabilidade institucional (DOMINGUEZ e LINDENBERG, 1997). A presença de fundos e organismos internacionais, como o Banco Interamericano de Desenvolvimento (BID) e o Programa das Naçóes Unidas para o Desenvolvimento (PNUD), tem sido fundamental para a promoção e financiamento de projetos que fomentam simultaneamente a participação e a governabilidade democrática. $\mathrm{O}$ envolvimento ativo de agências de cooperação, como a Agência dos Estados Unidos para o Desenvolvimento Internacional (USAID) e a Corporação Alemã para a Cooperação Internacional (GIZ), tem desempenhado um papel fundamental na implementação e condução de programas de supervisão participativa (por exemplo, de serviços de saúde) e para o desenvolvimento de iniciativas de transparência (por exemplo, em gastos públicos) por parte de organizaçóes da sociedade civil (MACDONALD, 1994).

Nesse contexto, o compromisso do México, Honduras, El Salvador, Guatemala e República Dominicana com a primeira geraçáo da Parceria para Governo Aberto (OGP) desde 2011, juntamente com Panamá e Costa Rica a partir de 2012, também se traduziu em um número significativo de políticas de planejamento participativo para transparência governamental e acesso à informação pública, orientando a adoção de estratégias muito avançadas de dados abertos e governo digital na regiáo ${ }^{7}$. Exemplos notáveis são as Jornadas de Consulta Oficial de Gobierno Abierto, em Honduras, o Consejo de Gobierno Abierto na Cidade do México (CDMX) e as etapas participativas do Plano de Governo Aberto na Costa Rica.

\section{Inovações democráticas nos Andes}

Não apenas uma geografia compartilhada e uma história comum de culturas pré-colombianas, mas também a alta porcentagem da população pertencente a minorias indígenas e étnicas, fazem dos países andinos uma região singular na América Latina. Alguns desses países reconheceram em constituiçóes recentes uma natureza plurinacional e multiétnica em suas democracias e, em certa medida, incorporaram

\footnotetext{
${ }^{7} \mathrm{O}$ site da Open Government Partnership (<www.opengovpartnership.org/> [acesso em 25 de Março de 2021) oferece informaçóes detalhadas sobre os compromissos de cada país e a taxa de progresso em seu cumprimento.
} 
formas tradicionais de organização comunitária em seus sistemas representativos (NOLTE e SCHILLING-VACAFLOR, 2016). Isso levou a incorporação de uma combinação de princípios participativos, comunais e representativos, especialmente na Bolívia, Equador e Venezuela, países cujas novas constituições buscaram "refundar" a política e a democracia (CAMERON e SHARPE, 2010).

O caso da Bolívia é único na região, com $62 \%$ de sua população identificada como descendente de indígenas entre os 36 povos originários de seu território, e uma transição democrática que chegou após um período de 20 anos de regime militar autoritário. O final do século 20 encontrou a Bolívia enfrentando extrema pobreza, desigualdade e instabilidade política e econômica, condiçôes que levaram à formação de poderosos movimentos sociais de camponeses e cocaleiros. Seu papel na vida política do país se fortaleceu desde a década de 1990, graças aos avanços legislativos iniciais sobre participação e descentralização, incluindo a Lei de Participação Popular (1994) e a Lei de Descentralização Administrativa (1995). Com base nesses atos legislativos, várias inovaçóes participativas foram adotadas no contexto do governo neoliberal que precedeu a virada à esquerda da Bolívia. Exemplos marcantes foram os Diálogos Nacionais de 1997, 2000 e 2004, espaços de pactos e negociaçóes entre o Estado e a sociedade civil para a formulação e implementação de políticas públicas de longo prazo para a redução da pobreza em âmbito nacional. O diálogo de 1997 engajou mais de 2 mil participantes em mesas redondas, conferências e workshops em 300 municípios (ROCA, 2005).

O Movimiento al Socialismo (MAS) de Evo Morales chegou à presidência nacional em 2005, defendendo uma democracia participativa de consenso. Como primeiro presidente indígena da Bolívia, ele convocou uma nova Assembleia Constituinte, o que em si foi um processo altamente participativo. A nova Constituição, aprovada por um referendo nacional em 2009, reconheceu a Bolívia como um Estado plurinacional e adotou uma "democracia participativa, representativa e comunal" como forma de governo (Artigo 11). Isso permitiu um governo descentralizado, profundamente enraizado em formas comunais de organização e voltado para a inclusão política de grupos historicamente marginalizados. Conselhos plurinacionais de cultura, conselhos de saúde e conselhos de planejamento e desenvolvimento urbano são exemplos de inovaçóes democráticas adotadas nos níveis local, regional e nacional, permitindo que cidadáos e comunidades definam agendas políticas de forma autônoma. Comitês de gestão compostos por cidadãos autodesignados também se espalharam para administrar o acesso à água, fornecer 
serviços sanitários, conduzir educação rural e comunitária e regular o uso de recursos naturais.

No entanto, nos últimos anos a Bolívia tem enfrentado várias crises, desde a candidatura de Evo Morales às eleiçôes de 2019, ignorando o resultado de um referendo, incluindo um governo de fato e escândalos de corrupçáo durante a pandemia. Em consequência, a sociedade civil tem implementado iniciativas de monitoramento e observação para garantir disputas eleitorais limpas e gratuitas, como o Observa Bolívia e Eu Informo. Em 2019, o país registrou as taxas mais altas de feminicídios na região, fazendo com que várias inovaçôes recentes tivessem por foco a igualdade de gênero e os direitos das mulheres, como, por exemplo, o Observatório da Justiça Tributária das Mulheres e o Observatório de Gênero da Coordenadora da Mulher.

A nova Constituição do Equador, ratificada por um referendo em 2008, também é considerada radicalmente democrática em muitos aspectos: não apenas enfatiza a participação e a inclusão, mas também reconhece os direitos legalmente aplicáveis à natureza e ao bem viver (Buen Vivir). Precedida pela Lei de Descentralização e Participação Social de 1997 e posteriormente complementada pela Lei de Participação Cidadã de 2010, a reforma do país institucionalizou ainda mais a participação política, a igualdade, a justiça social e o multiculturalismo. Sob a presidência de Rafael Correa (2007-2017), amplamente apoiado no início de seu governo por diversos movimentos sociais, a inclusão política de cidadãos e organizações de base foi foco de inovaçóes democráticas, por exemplo, um sistema nacional e multinível de formulação de políticas por meio de Conselhos para a Igualdade e de Conselhos de Participação Cidadã e Acompanhamento Social.

O estabelecimento de objetivos estratégicos e a definiçáo de diretrizes governamentais em cada área de políticas públicas são deixados para conselhos deliberativos de nível nacional, como o Conselho Nacional para a Igualdade dos Povos e Nacionalidades, a Assembleia Plurinacional e Intercultural de Cidadãos para o Bem Viver, e a Conferência Plurinacional e Intercultural de Soberania Alimentar. No entanto, esse sistema não passou sem crítica, pois as inovaçóes participativas criadas sob os três mandatos de Correa dependeram fortemente do governo, e as organizaçóes 
participantes foram principalmente aquelas que apoiavam Alianza PAIS, o partido de Correa ${ }^{8}$.

No contexto da crescente oposição ao 'Correismo' devido às difíceis condições econômicas no país, o número de inovaçóes democráticas iniciadas por atores da sociedade civil cresceu. Desde a mudança de governo em 2017, e a virada neoliberal do sucessor Lenin Moreno, essas inovaçôes têm desempenhado um papel fundamental como órgãos de fiscalização na busca pela responsabilização e transparência do governo diante de escândalos de corrupção como os da Odebrecht e dos Panama Papers. Exemplos são as campanhas "Cuidado com o nosso Dinheiro" e o Dataton Anticorrupção.

No Peru, a experimentação e a inovação com instituiçóes democráticas remontam aos processos de descentralização de meados dos anos 1980 e início dos anos 1990. Desde a reforma constitucional de 1993, no entanto, os mecanismos de participação foram institucionalizados principalmente por meio de legislação. Uma lei de direitos de participação e monitoramento do cidadáo foi promulgada em 1994, seguida pela Lei de Descentralização em 2002 e um marco legislativo nacional para o sistema mandatório de orçamento participativo em 2003. O longo conflito armado com as guerrilhas do Sendero Luminoso, e a posterior renúncia de Alberto Fujimori em 2000, como consequência de graves violaçóes dos direitos humanos durante o conflito e escândalos de corrupção, levaram à adoção de um grande número de espaços de deliberação e colaboração com a sociedade civil como resposta à crise política. Foi o caso do Fórum do Acordo Nacional, amplo espaço deliberativo que reúne representantes do Poder Executivo, partidos políticos e organizaçóes da sociedade civil, encarregado de acertar os arranjos institucionais para a transição política pós-crise.

Modelos deliberativos semelhantes foram utilizados para resolver questôes de desigualdade e pobreza extrema, como, por exemplo, as Mesas de Concertación para la Lucha contra la Pobreza, que se tornou uma instituição permanente que ainda hoje permite aos cidadãos participarem de diversos programas de governança. Outros órgãos de cidadãos focados no combate à corrupção e na garantia de transparência e responsabilidade compartilham esse formato institucional deliberativo. Por exemplo, a Mesa de Diálogo Permanente para a Solução dos Problemas das Comunidades Indígenas da Amazônia Peruana estabeleceu as bases para respostas participativas ao

\footnotetext{
${ }^{8}$ Para uma perspectiva crítica dos espaços participativos iniciados pela Executiva Nacional do Equador, ver Ortiz Lemos (2015); e Conaghan (2008) para uma avaliação diferente da participação promovida durante a presidência de Correa.
} 
conflito de Bagua de 2009 (ou "Baguazo"). Os esforços para incluir as comunidades indígenas levaram à adoção de legislação inovadora sobre proteção ambiental e gestão de recursos naturais. Resultados desses processos de diálogo são, por exemplo, a elaboração coletiva com as populações indígenas da Lei de Florestas e Vida Selvagem de 2011, seguida pelo esforço colaborativo para a elaboração do marco legal da Consulta Prévia.

No entanto, os últimos anos testemunharam uma sucessão de crises políticas no Peru, principalmente como consequência da hostilidade entre os poderes legislativo e executivo, que levaram à renúncia do presidente Pedro Pablo Kuczynski em 2018 e de seu sucessor Martín Vizcarra em 2020. A sucessão de três presidentes em uma semana durante a crise de 2020, e o envolvimento de todos os ex-presidentes ainda vivos em escândalos de corrupção, geraram grande desconfiança em futuros processos eleitorais. A proteção das garantias eleitorais e o controle do cumprimento da lei sáo os temas que mais ocupam a sociedade civil na atualidade.

A Colômbia, por sua vez, segue uma história adjacente aos acontecimentos na América Central, sofrendo com um conflito de décadas entre as forças armadas e grupos guerrilheiros radicalizados. No entanto, a crise política que se seguiu a esse conflito abriu espaço para as reivindicaçôes populares por uma nova Constituição, que em 1991 propôs o processo de descentralização e autonomia para regióes e municípios e incluiu a participação dos cidadáos não apenas como um direito fundamental, mas também como dever de todos os cidadãos "[participar] na vida política, cívica e comunitária do país” (Artigo 95). O grau de institucionalização das inovaçóes participativas na Colômbia é o mais alto da regiáo, começando pela legislação inicial sobre descentralização em 1986 e seu complemento, a Lei de Participação 134, de 1994. Um número significativo de inovaçóes foi criado por lei, incluindo a participaçáo de cidadãos e organizações da sociedade civil em conselhos e comitês de planejamento em todos os níveis do governo em áreas como educação, saúde, desenvolvimento, ciência e tecnologia e cultura e patrimônio, entre muitas outras. A inclusão política de minorias étnicas e culturais está no centro dessa legislação, bem como o desenvolvimento rural e urbano e as políticas para jovens, elaboradas com contribuiçôes fornecidas por órgãos deliberativos comunitários, distritais e departamentais.

Desde então, o país se destaca por uma diversidade de experiências de monitoramento cidadão bem sucedidas. Modelos de redes locais de supervisão que surgiram na Colômbia se expandiram para toda a América Latina, como a Red de Ciudades Cómo Vamos, que se espalhou por toda a região e levou à criação da Rede Latino-americana de Cidades e Territórios Justos, Democráticos e Sustentáveis. Mais 
recentemente, tecnologias digitais têm sido implementadas tanto pelo governo quanto pela sociedade civil para fortalecer a transparência. Alguns exemplos dessa tendência são o Urna de Cristal no nível nacional e Bogotá Aberta no nível local, assim como o Mapa Político e Candidater do lado da sociedade civil.

No entanto, o conflito guerrilheiro continua marcando a vida política colombiana. Numerosas tentativas abordaram os efeitos do conflito, documentando crimes e incluindo os interesses dos cidadáos, e especialmente das vítimas, nas negociaçôes políticas para a paz. Essas iniciativas incluíram a Asamblea Permanente de la Sociedad Civil pela Paz e o Mandato Ciudadano pela Paz, la Vida y la Libertad em 1996; Conselhos Nacionais e Regionais de Paz em 1998; o Pacto Nacional por la Paz entre 2013-2016; o Acuerdo Nacional de Mínimos de Reconciliação e Paz em 2009; Encontros Regionais pela Paz em 2014 e 2015; e, finalmente, as negociaçóes de 2016 para os Acordos de Paz e o plebiscito que os seguiu.

Finalmente, o caso venezuelano é o que escapa todas as generalidades. Sendo o país que trouxe as reformas da virada à esquerda a sua extensão máxima sob o polêmico governo de Hugo Chávez, sua experimentação com um modelo econômico e político radical de democracia participativa só pode ser compreendido considerando a história específica do país, sua extrema desigualdade, e sua relação conflituosa com os Estados Unidos e com a indústria de hidrocarbonetos. A revolucionária Constituição Bolivariana de 1999 não só criou dois poderes adicionais do Estado, o Poder Cidadão e o Poder Eleitoral, mas também estabeleceu em seu preâmbulo que a Venezuela é uma república baseada em "uma sociedade democrática, participativa e protagonista”. Essas reformas institucionais se enraizaram fortemente no nível comunal e no uso intensivo de consultas e referendos para apoiar as políticas nacionais e estratégias administrativas. Foi este o caso, por exemplo, do referendo para a Assembleia Nacional Constituinte de 1999 e o consequente referendo para aprovar o projeto de Constituição resultante desse processo, assim como os referendos para as emendas constitucionais de 2007 e 2009 e as consultas para a revogação do mandato presidencial de Hugo Chávez em 2003 e 2004.

A nível local, conselhos comunitários locais formados exclusivamente por cidadáos receberam extensos poderes para gerir a administração local, bens e serviços públicos. Em 2009, havia cerca de 30 mil conselhos comunitários ativos em todo o país e uma estimativa de oito milhóes de participantes (GARCIA-GUADILLA, 2008). Os bens e serviços públicos também passaram a ser administrados por conselhos de cidadáos, como conselhos técnicos de energia, comitês de terras urbanas e rurais, 
conselhos técnicos de água e até mesmo empresas comunais de propriedade social direta. Como mostram esses exemplos, a extensão da reforma política e social da Venezuela exigiu um amplo debate para compreender suas condiçóes e consequências e para avaliar sua eficácia. Os resultados dessas experiências institucionais foram criticados por serem fortemente influenciados pela polarização política (HAWKINS, 2010; MCCARTHY, 2012), trazendo para o debate a condição democrática da Venezuela, especialmente à luz das crises cíclicas que o país enfrentou e das consequências econômicas e sociais dramáticas das permanentes disputas políticoinstitucionais. A oposição liderada pelo autoproclamado presidente Juan Guaidó tem organizado iniciativas para sustentar sua legitimidade, como a Consulta Nacional de 2017, contra a nova reforma constitucional promovida por Maduro, e os Comitês de Socorro e Liberdade, espaços comunitários orientados a resolver as necessidades urgentes e dialogar sobre a situação no país.

Mais recentemente, as dificuldades enfrentadas pela sociedade civil para participar foram exacerbadas pela repressão aos protestos, pela emigração em massa e pela grave crise econômica. Ao contrário do resto da regiáo, o país teve um crescimento modesto e tardio no uso de ferramentas de participação digital. A mobilização cidadã enfrenta principalmente desafios de abastecimento de bens e serviços básicos, para o que foram organizadas assembleias e campanhas nos bairros e nas comunidades.

\section{Participação e Inovação durante a Pandemia de Covid-19}

A chegada da pandemia na América Latina foi a crônica de uma emergência anunciada. Tratando-se de uma regiáo caracterizada por baixa capacidade estatal e alta desigualdade social, a crise sanitária provocada pela rápida expansão da Covid-19 se viu agravada por uma série de problemas políticos, econômicos e sociais. Protestos massivos tomaram as ruas do Chile e do Peru, derrubando o presidente neste último país. Equador, Peru e Brasil também dominaram em diferentes momentos o triste ranking mundial de número de infecçóes e mortes pela enfermidade, ao passo que na Nicarágua a própria existência da doença foi negada. $\mathrm{Na}$ Argentina, onde o governo tomou medidas responsável desde o início, o cansaço devido à quarentena mais longa do mundo e a premente crise econômica acabaram deslegitimando as medidas de cuidado. A liderança política na região foi, em muitos casos, ausente, se não mesmo irresponsável e incompetente, como no Brasil. Nem mesmo as histórias de sucesso no gerenciamento da pandemia no Uruguai e no Paraguai prepararam esses países para a segunda onda.

Tais cenários tornam evidentes os limites dos governos e a herança estrutural de exclusão e desigualdade, deixando a gestão das respostas em boa medida nas mãos 
da sociedade civil e das comunidades auto-organizadas. Esta foi a primeira conclusão a que chegamos depois de realizar um mapeamento das respostas dos governos e da sociedade civil durante a primeira onda da pandemia ${ }^{9}$. No último ano, organizaçóes da sociedade civil criaram um enorme número de iniciativas destinadas a mitigar os problemas relacionados à pandemia. Nosso mapeamento em 18 países da América Latina revelou mais de 100 novas instituiçôes, processos e mecanismos que se valem da participação cidadã para responder aos problemas sociais, políticos e sanitários relacionados à pandemia. Além disso, identificamos cerca de 300 açôes, campanhas e projetos levados a cabo por organizaçóes da sociedade civil, setores privados ou coletivos de cidadáos com o intuito de mitigar o impacto da pandemia ainda que sem se valer da participação direta da cidadania.

Essas inovaçôes democráticas e iniciativas da sociedade civil têm ao menos três fatores em comum, independentemente de incluírem ou não a participação dos cidadãos e cidadãs. Primeiro, todas usaram as ferramentas digitais como canal principal para convocar, organizar e executar as respostas à pandemia. Segundo, essas tecnologias funcionaram como catalisadores de inteligência coletiva e social, possibilitando a construçáo colaborativa de processos e soluçóes a partir de conhecimentos, dados e informações providas por cidadãos e cidadâs (POGREBINSCHI, 2020). Terceiro, a natureza e o escopo dessas iniciativas transcendem as fronteiras nacionais. Exemplos notáveis dessa tendência, que também é conhecida como crowdsourcing, são os hackathons e plataformas digitais transnacionais como o Freia a curva (no Brasil, também chamado de Segura A Onda), uma plataforma online onde voluntários, empreendedores, ativistas, organizaçôes sociais, criadores e laboratórios de inovação cooperam para identificar soluçóes para os problemas específicos causados pela pandemia, diretamente nos territórios. O projeto foi lançado na Espanha, mas foi estendido a 12 países latino-americanos e vários outros ao redor do mundo. Algo semelhante aconteceu com hackathons lançados simultaneamente em vários países, como o Latin America vs Covid-19 Challenge, coordenado pelo laboratório do MIT, ou o Hackathon latino-americano "Cada dia conta".

\footnotetext{
9 O mapeamento de inovaçóes democráticas e iniciativas da sociedade civil durante a pandemia na América Latina foi realizado pela equipe do projeto Latinno durante os meses de março a julho de 2020. Os resultados podem ser consultados em www.latinno.net/pt/covid (iniciativas da sociedade civil) e por meio de da ferramenta de buscas do banco de dados em www.latinno.net/pt/innovations (para casos de inovações democráticas).
} 
Um quarto fator em comum é o alto envolvimento da sociedade civil, responsável por iniciar aproximadamente $75 \%$ das inovaçôes e iniciativas mapeadas. Essas açôes podem ser distinguidas, por sua vez, em alguns tipos que se repetiram em todo o continente. Um primeiro tipo foram as iniciativas para observar e monitorar a ação do governo e dados públicos sobre a pandemia. Assim, foram criados observatórios independentes para monitorar número de casos e mortes em países onde os números oficiais geravam desconfiança ou não eram divulgados abertamente, como o Observatório Brasil.io no Brasil, o Observatório Covid-19 em El Salvador, e o Observatório Cidadão Covid-19 na Nicarágua. Outras iniciativas foram dedicadas ao monitoramento de gastos públicos e compras de equipamentos e insumos de saúde, em países onde a preocupação com a corrupção é alta. É o caso do Monitoramento Cidadão de Contratos Públicos no Equador, a iniciativa de Compra Eficiente na Colômbia, ou a Lupa sobre as transferências no Peru. Adicionalmente, alguns órgãos coletivos foram criados para aconselhar os governos no direcionamento de respostas à pandemia, como a Mesa de Trabalho LGTBI e COVID-19 no Chile, a Mesa Redonda do Setor de Saúde na Costa Rica, ou o Conselho Consultivo para Gestão Ambiental Posto Covid-19 na Panamá.

Um último tipo de iniciativa amplamente expandida durante a pandemia foram as plataformas colaborativas de apoio mútuo em nível local. Fazendo uso de tecnologias de geolocalização, essas plataformas - hospedadas em páginas da internet ou aplicativos para smartphone - foram desenvolvidas para conectar demandas de indivíduos e organizaçóes necessitadas com a disponibilidade de outros indivíduos e organizaçóes dispostos a fornecer o que se faz necessário. Alguns exemplos são o projeto Bolívia Solidaria, a plataforma Eu Quero Ajudar no México, o Bazar de Ofertas e Necessidades Covid na República Dominicana, o Mapa de Soluçóes em Honduras, ou a web Wendá no Paraguai.

O desenvolvimento rápido e coordenado desta variedade de iniciativas indica que, embora a capacidade estatal náo possa ser construída da noite para o dia, a inteligência coletiva é um recurso ilimitado e permanentemente disponível. O conceito de inteligência coletiva explica a natureza desses recursos e se revela como uma poderosa ferramenta para governos que enfrentam problemas difíceis e desafios sem precedentes: a agregação e o compartilhamento de conhecimentos, informaçóes, habilidades, recursos e dados, transformando as cidadâs e cidadáos comuns em solucionadores de problemas sociais e políticos. 


\section{Lições, direções e aprendizados}

Os estudos sobre inovaçóes democráticas frequentemente ressaltam como a América Latina se destaca das outras regióes do mundo pelo amplo experimentalismo político que visa incluir os cidadáos nos processos de tomada de decisão (FUNG, 2011; PATEMAN, 2012). Essa afirmação tem se baseado principalmente no caso de sucesso do orçamento participativo, que se espalhou de Porto Alegre para centenas de cidades em todo o continente e de lá para o mundo (SINTOMER et al., 2010). Neste capítulo, no entanto, procuramos destacar a diversidade de novos formatos institucionais de participação cidadã que têm evoluído na América Latina, mostrando como sua adoção tem sido vinculada à própria diversidade de contextos políticos e sociais que configuram a regiáo.

Se as inovaçóes democráticas na América Latina realmente se destacam, e se isso não acontece somente devido à experiência bem-sucedida de um único formato institucional, por que isso acontece? Nossa revisáo do contexto histórico de cada subregião e de algumas das principais inovaçôes democráticas criadas em relação a elas deixou claro um aspecto importante que é comum a quase todos os 18 países que cobrimos: as inovaçóes democráticas na América Latina tendem a ser institucionalizadas.

O fato de as inovaçóes democráticas serem institucionalizadas significa que estão embutidas em constituiçóes e estruturas legais, que muitas vezes prescrevem uma implementação obrigatória (embora raramente tornem compulsórias as decisóes de tais instâncias participativas). Esse aspecto formal molda um cenário no qual as inovaçôes democráticas são em sua maioria implementadas pelo Estado, patrocinadas por governos e partidos políticos em ambos lados do espectro ideológico. O papel ativo da administração pública e a disposição dos governos em fazer efetivos os novos formatos institucionais por eles elaborados podem explicar seu sucesso em alguns casos, como aparentemente aconteceu em Porto Alegre no início dos anos 1990 (BAIOCCHI e GANUZA, 2012). No entanto, a iniciativa do Estado não é suficiente para que as instituiçóes participativas alcancem a implementação total, com o que em muitos casos acabam existindo apenas no papel (MCNULTY, 2015).

O processo de institucionalização das inovações democráticas na América Latina, como fica claro ao longo deste capítulo, tem duas raízes principais: descentralização e constitucionalização. Esses dois aspectos superam a diversidade de contextos históricos, enquadrando um pano de fundo comum que parece explicar por que a experimentação democrática e a participação cidadã encontraram solo fértil para 
crescer em toda a regiáo. Além disso, essas duas tendências estão no cerne do processo de democratização da América Latina, pois reforçam a transição do regime autoritário, contribuindo para o argumento de que novas práticas e instituiçóes de participação cidadã não podem ser dissociadas das próprias lutas e significados que a democracia alcançou no continente (O'DONNELL, SCHMITTER e WHITEHEAD, 1986).

Embora a consolidação democrática tenha sido alcançada em praticamente todos os países da regiáo, a América Latina nunca se ajustou efetivamente aos modelos liberais de democracia e talvez nunca o faça, porque por aqui se desenvolveu um modelo diferente de democracia, que não pode ser facilmente medido com os padronizados indicadores ocidentais (POGREBINSCHI, 2013 e 2017). Ao mesmo tempo, essa peculiaridade da democracia na América Latina torna as inovaçôes que aqui surgiram de certa forma únicas, no sentido de que são fortemente emolduradas pelos contextos políticos e sociais e pelas narrativas específicas dos países em que se desenvolveram. Isso explica por que variaçôes na extensão, duração e impacto das inovaçôes dependem dos níveis de estabilidade institucional e qualidade democrática alcançados por cada país. Isso também pode explicar por que as tentativas de replicar essas experiências em outras partes do mundo podem continuar sendo malsucedidas como ocorreu com o orçamento participativo, que acabou se espalhando como algo bem diferente da inovação democrática adotada pela primeira vez em Porto Alegre (BAIOCCHI e GANUZA, 2012; CABANNES, 2004).

Em todo caso, embora fazer conceitos viajarem seja tão difícil quanto encontrar universais empíricos (SARTORI, 1970), se a América Latina tem uma lição a oferecer sobre as inovaçóes democráticas, talvez seja que a experimentação deve coexistir com a institucionalização. Se a participação da cidadania no processo político significa uma ruptura, uma descontinuidade em relação a uma forma anterior de experimentar a democracia e, portanto, uma inovação, esses novos modos de fazer política requerem, ao mesmo tempo, algum grau de formalização e inserção no sistema representativo. 
Thamy Pogrebinschi é Pesquisadora Senior do Centro de Ciências Sociais de Berlim (WZB), Professora da Escola de Pós-Graduação em Ciências Sociais (BGSS) da Universidade Humboldt de Berlim e Coordenadora do Projeto LATINNO (www.latinno.net). E-mail: thamy.pogrebinschi@wzb.eu.

- Melisa Ross é Doutoranda na Universidade Humboldt de Berlim e Pesquisadora Associada no Projeto LATINNO. E-mail: melisa.ross@wzb.eu.

\section{Referências}

ALTMAN, David. Direct Democracy Worldwide. Cambridge: Cambridge University Press, 2011.

AVRITZER, Leonardo. Democracy and the Public Space in Latin America. Princeton: Princeton University Press, 2002.

AVRITZER, Leonardo. Participatory Institutions in Democratic Brazil. Baltimore: John Hopkins University Press, 2009.

BAIOCCHI, Gianpaolo. Radicals in Power: The Workers' Party and Experiments in Urban Democracy in Brazil. London: Zed Books, 2003.

BAIOCCHI, Gianpaolo; GANUZA, Ernesto. Popular Democracy: The Paradox of Participation. Stanford: Stanford University Press, 2012.

BAY-MEYER, Kelly. Do Ortega's citizen power councils empower the poor in Nicaragua? Benefits and costs of local democracy. Polity, v. 45, n. 3, p. 393-421, 2013.

CABANNES, Yves. Participatory budgeting: A significant contribution to participatory democracy. Environment and Urbanization, v. 16, n. 1, p. 27-46, 2004.

CAMERON, Maxwell A.; HERSHBERG, Eric; SHARPE, Kenneth (Eds.). New Institutions for Participatory Democracy in Latin America: Voice and Consequence. New York: Palgrave Macmillan, 2012.

CAMERON, Maxwell A.; SHARPE, Kenneth. Andean left turns: Constituent power and constitution making. In: CAMERON, Maxwell A.; HERSHBERG, Eric (org..). Latin Americas Left Turns: Politics, Policies, and Trajectories of Change. Boulder: Lynne Rienne Publishers, 2010. p. 61-79.

CAMPBELL, Tim. The Ouiet Revolution: Decentralization and the Rise of Political Participation in Latin American Cities. Pittsburgh: University of Pittsburgh Press, 2003.

COELHO, Vera Schattan P. A democratização dos Conselhos de Saúde: O paradoxo de atrair não aliados. Novos Estudos, n. 78, p. 77-92, 2007.

CONAGHAN, Catherine. Ecuador: Correa's plebiscitary presidency. Journal of Democracy, v. 19, n. 2, p. 46-60, 2008.

DE LA JARA, Felipe J. Hevia; VERA, Ernesto. Constrained participation: The impact of consultative councils on nationallevel policy in Mexico. In: CAMERON, Maxwell A.; HERSHBERG, Eric; SHARPE, Kenneth (org.). 
New Institutions for Participatory Democracy in Latin America: Voice and Consequence. New York: Palgrave Macmillan, 2012. p. 75-98.

DINERSTEIN, Ana. ¡Que se vayan todos! Popular insurrection and the Asambleas Barriales in Argentina. Bulletin of Latin American Research, v. 22, n. 2, p. 187-200, 2003.

DOMINGUEZ, Jorge I.; LINDENBERG, Marc (org.). Democratic Transitions in Central America. Gainesville, FL: University Press of Florida, 1997.

FALLETI, Tulia. A sequential theory of decentralization: Latin American cases in comparative perspective. American Political Science Review, v. 99, n. 3, p. 327-346, 2005.

FALLETI, Tulia; RIOFRANCOS, Thea. Endogenous Participation: Strengthening Prior Consultation in Extractive Economies. World Politics, v. 70, n. 1, p. 86-121, 2018.

FUNG, Archon. Reinventing democracy in Latin America. Perspectives on Politics, v. 9, n. 4, p. 857-871, 2011.

GARCIA-GUADILLA, María Pilar. La praxis de los consejos comunales en Venezuela: poder popular o instancia clientelar. Revista Venezolana de Economía y Ciencias Sociales, v. 14, n. 1, p. 125-151, 2008.

GIMENEZ-CABALLERO, Edgar; RODRIGUEZ, José Carlos; PERALTA, Néstor. Decision spaces on health decentralization in Paraguay. Memorias del Institute de Investigaciones en Ciencias de la Salud, v. 14, n. 3, p. 44-51, 2016.

GOLDFRANK, Benjamin. Deepening Democracy in Latin America: Participation, Decentralization and the Left. University Park: Pennsylvania State University Press, 2011.

HAWKINS, Kirk. Who mobilizes? Participatory democracy in Chavez's Bolivarian revolution. Latin American Politics and Society, v. 52, n. 1, p. 31-66, 2010.

LEVITSKY, Steven; MURILLO, María. Argentina: From Kirchner to Kirchner. Journal of Democracy, v. 19, n. 2, p. 16-30, 2008.

LEVITSKY, Steven; ROBERTS, Kenneth (Eds). The Resurgence of the Latin American Left. Baltimore: John Hopkins University Press, 2011.

LISSIDINI, Alicia. Direct democracy in Uruguay and Venezuela: New voices, old practices. In: CAMERON, Maxwell A.; HERSHBERG, Eric; SHARPE, Kenneth (org.). New Institutions for Participatory Democracy in Latin America: Voice and Consequence. New York: Palgrave Macmillan, 2012. p. 149-180.

LÓPEZ MAYA, Margarita. Caracas: The state, popular participation, and how to make things work. Conferência The popular sectors and the state in Chavez's Venezuela, New Haven: Yale University, 2008.

LUNA, Juan. Frente Amplio and the crafting of a social democratic alternative in Uruguay. Latin American Politics and Society, v. 49, n. 4, p. 1-30, 2007.

MACDONALD, Laura. Globalising civil society. Interpreting international NGOs in Central America. Millennium, v. 23, n. 2, p. 267-285, 1994.

MARSTEINTREDET, Leiv; LLANOS, Mariana; NOLTE, Detlef. Paraguay and the Politics of Impeachment. Journal of democracy, v. 24, n. 4, p. 110-123, 2013.

MCCARTHY, Michael M. The possibilities and limits of politicized participation: Community councils, coproduction, and poder popular in Chavez's Venezuela. In: CAMERON, Maxwell A.; HERSHBERG, Eric; SHARPE, Kenneth (org.). New Institutions for Participatory Democracy in Latin America: Voice and Consequence. New York: Palgrave Macmillan, 2012. p. 123-148.

MCNULTY, Stephanie. Mandating participation: Evaluating Guatemala's top-down participatory governance system. Pensamiento Propio, v. 40, p. 95-124, 2015.

NINO, Carlos. Transition to democracy, corporatism and constitutional reform in Latin America. University of Miami Law Review, v. 44, p. 129-155, 1989.

NOLTE, Detlef; SCHILLING-VACAFLOR, Almut (org.). New Constitutionalism in Latin America: Promises and Practices. New York: Routledge, 2016.

O'DONNELL, Guillermo; SCHMITTER, Phillipe; WHITEHEAD, Laurence (org.). Transitions from authoritarian rule: tentative conclusions. Baltimore: John Hopkins University Press, 1986. 
ORTIZ LEMOS, Andres. Taking Control of the Public Sphere by Manipulating Civil Society: The Citizen Revolution in Ecuador. European Review of Latin American and Caribbean Studies, v. 98, p. 29-48, 2015.

PATEMAN, Carole. Participatory democracy revisited. Perspectives on Politics, v. 10, n. 1, p. 7-19, 2012.

PERUZZOTTI, Enrique; SMULOVITZ, Catalina (org.). Enforcing the Rule of Law: Social Accountability in the New Latin American Democracies. Pittsburgh: University of Pittsburgh Press, 2006.

POGREBINSCHI, Thamy. Might social intelligence save Latin America from its governments in times of Covid19? Open Democracy, Aug. 18, 2020. Available at: <https://www.opendemocracy.net/en/ democraciaabierta/puede-la-inteligencia-social-salvar-a-america-latina-de-sus-gobiernos-en-tiempos-de-coviden/>. Access on: Apr. 28, 2021.

POGREBINSCHI, Thamy. Experimenting with participation and deliberation in Latin America: Is democracy turning pragmatic? In: FALLETI, Tulia; PARRADO, Emilio (org.). Latin America Since the Left Turn. Philadelphia: University of Pennsylvania Press, p. 241-263, 2017.

POGREBINSCHI, Thamy. The squared circle of participatory democracy: Scaling up deliberation to the national level. Critical Policy Studies, v. 7, n. 3, p. 219-241, 2013.

POGREBINSCHI, Thamy; SAMUELS, David. The impact of participatory democracy: Evidence from Brazil's National Public Policy Conference. Comparative Politics, v. 46, n. 3, p. 313-332, 2014.

POGREBINSCHI, Thamy; TANSCHEIT, Talita. Andando para Trás: O que Aconteceu com a Participação Social no Brasil? Open Democracy/Democracia Abierta, November 30, 2017. Disponível em: https://www.opendemocracy.net/pt/andando-para-tr-s-o-que-aconteceu-com-particip/. Acesso em: $25 \mathrm{mar}$. 2021.

ROCA, Carlos Toranzo. La experiencia boliviana: 'Diálogo Nacional: Bolivia hacia el siglo XXI’y 'Diálogo Nacional 2000: lucha contra la pobreza'. Diálogo Social en América Latina: Un Camino Hacia la Democracia Ciudadana, p. 71-92, 2005.

ROSENBAUM, Allan; RODRIGUEZ-ACOSTA, Cristina; ROJAS, Maria Victoria. Decentralizing the health service delivery system in an emerging democracy: A case study of organizational change, civil society participation and local institution building in Paraguay. International Review of Administrative Sciences, v. 66, n. 4, p. 655672, 2000.

SARTORI, Giovanni. Concept misformation in comparative politics. American Political Science Review, v. 64, n. 4, p. 1033-1053, 1970.

SELEE, Andrew; PERUZZOTTI, Enrique (org.). Participatory Innovation and Representative Democracy in Latin America. Washington: Woodrow Wilson Center Press, 2009.

SINTOMER, Yves; HERZBERG, Giovani; RÖCKE, Anja. Learning from the South: Participatory budgeting worldwide - an invitation to global cooperation. Dialog Global, n. 25, p. 2-17, 2010.

SITRIN, Marina (org.). Horizontalism: Voices of Popular Power in Argentina. Oakland: AK Press, 2006.

WAMPLER, Brian. Participatory' Budgeting in Brazil: Contestation, Cooperation, and Accountability. Pennsylvania: Penn State University Press, 2007.

ZAREMBERG, Gisela, MUÑOZ, María. Redes y Jerarquías: Participacion, Representationy Gobernanza Local en America Latina. Ciudad de Mexico: FLACSO, 2012.

\section{Texto recebido em 26 de março de 2021. Aprovado em 30 de março de 2021.}

